BISMA

(Bisnis dan Manajemen)
Volume 13, Issue 2, April 2021, 121-134

ISSN 2549-7790 (Online)

ISSN 1979-7192 (Print)

DOI: 10.26740/bisma.v13n2.p121-134

https://journal.unesa.ac.id/index.php/bisma/index

\title{
The factor analysis of demographic, purchasing behaviour, and customer satisfaction of budget hotel
}

\author{
Eliot Simangunsong*
}

Universitas Prasetiya Mulya, Indonesia

\begin{abstract}
Budget hotels are growing in Indonesia because of the increased number of business travellers and budget travellers. Nevertheless, budget hotels face increasingly fierce competition to attract customers and sustain growth. This research aims to identify factors that determine budget hotels' guest satisfaction. A quantitative approach with the survey as a research instrument has been applied and collected 363 respondents. Data analysis using SPSS shows that monthly spending, frequency of staying, and lifestyle factors are the main determinants of visitor's decision to stay in a budget hotel. This result indicates that the more prudent the visitor lifestyle, the more likely they will remain at a budget hotel. Furthermore, the Friedman test shows the degree of importance of each factor influencing guest satisfaction in a budget hotel. A posthoc analysis with Wilcoxon signed-rank tests (with Bonferroni correction) finds that cleanliness, price, and location become the utmost important factors determining guest satisfaction.
\end{abstract}

Keywords: budget hotel; satisfaction factors; service quality.

Received: January 23, 2020; Accepted: August 18, 2020; Published: April 282021

*Corresponding author

Email: elliot@pmbs.ac.id

To cite this document:

Simangunsong, E. (2021). The factor analysis of demographic, purchasing behaviour, and customer satisfaction of budget hotel. BISMA (Bisnis dan Manajemen), 13(2), 121-134. https://doi.org/10.26740/bisma.v13n2.p121-134.

\section{INTRODUCTION}

Hotels can be classified based on different criteria such as hotel size, locations, target markets, affiliation, and service level. In terms of the service level, Ting et al. (2016) explained two types of hotel, i.e., economy hotel (or budget hotel) and luxury hotel. The budget hotel is characterized by providing basic customer needs such as clean and tidy rooms. As for people who seek simple leisure such as only a bed and shower, the budget hotel has become an alternative, besides of low-cost meal. The business of budget hotels in Indonesia has enormous potential for growth as it is supported by market demand due to an increasing number of 
business travellers and budget travellers. Euromonitor International (2019) reported a consistent growth of budget hotels from 5483 hotels in 2014 to 7706 hotels in 2019.

As domestic and international travellers keep increasing, budget hotels are among the fastest-growing segments in Indonesia's hotel industry. For example, there is strong growth in foreign tourists' arrival from China who cautious about spending, especially when choosing airlines and lodging, which means they will tend to downsize them. On the other hand, the domination of low-cost carriers also happened in Indonesia, with a growing trend of online budget hotels such as Airy Rooms, RedDoorz, and Capsule Hotels. It shows travelling economically for travellers is no longer a problem (Euromonitor International, 2019).

The emergence of budget hotels in Indonesia was started with Formule-1 Hotel in Jakarta in 2006. This is a two-star hotel that offers a comfortable room than three-star hotels but at a lower price. Furthermore, in 2007, Santika Group (belong to Kompas Gramedia) began applying the same hotel concept and the Amaris brand by Santika also launched that located at Panglima Polim, South Jakarta. Like a magnet in property businesses, entrepreneurs, and companies did not want to miss a budget hotel's promising business opportunity. After Formule-1, Tune Hotels, and Amaris Hotel, there were many new budget hotels like Favehotel by Aston, @ HOM by Horison, POP! Hotel, Whiz Hotel, and Ibis Budget Hotel (Euromonitor International, 2020). Appendix 1 shows some statistics for four popular budget hotels in Indonesia. It is interesting to note that the popular budget hotels are star hotels. Ibis Budget Hotel is a three-star hotel, while Favehotel, POP! Hotel, and Amaris Hotel are two-star hotels.

Meanwhile, Appendix 2 shows starred and non-starred hotels' growth, with the highest number of starred hotels being three-starred hotels. The lowest number of starred hotels is fivestarred hotels. All kinds of starred hotels continuously increase from 2012 until 2019, except one-starred hotels. BPS (2019) also published data shows that star hotels have progressed from 2,387 (in 2016) to 3,516 (in 2019), or an increase of $47 \%$. At the same period, non-star hotels also increased 56\% from 16,442 (in 2016) to 25,727 (2019). This means that cheap hotels have increased sales better than luxury hotels (BPS, 2016; BPS, 2018; BPS, 2020).

BPS (2020) reported that the highest number of accommodations of starred hotels in Bali, which is 507 accommodation, followed by 495 hotels in West Java, 397 hotels in Greater Jakarta, 311 hotels in Central Java, and 258 in East Java. Furthermore, Bali's highest number of star hotels is 70.146 rooms, followed by Greater Jakarta with 55.800 rooms, West Java with 48.755 rooms, East Java with 27.485 rooms, and Central Java 25.630 rooms. The average length of stay in a hotel in 2017 was 2.90 days for international visitors and 1.77 days for domestic visitors (BPS, 2019).

Currently, budget hotels face severe challenges due to fierce competition in this industry. Thus, companies need an effective strategy to attract consumers since their competitors offer similar services (Euromonitor International, 2018; Ngelambong et al., 2016; Rahimi \& Kozak, 2017; Rozano \& Pamungkas, 2016). It is to be noted that most studies on budget hotels are more frequent in the US and the UK. Nevertheless, studies on fundamental factors of this emerging industry's success are limited to Asia's context (Ting et al., 2016). Moreover, researchers seldom examine a budget hotel's customer satisfaction (Ting et al., 2016; Ren et al., 2018). Some hospitality industry studies are relatively descriptive and inattentive to measurement issues (Nunkoo et al., 2017). 
The factor analysis of demographic, purchasing behaviour, and customer satisfaction of budget hotel

Previous research has identified factors that influence budget hotel customer satisfaction. However, their findings have differences. For example, some studies such as Ting et al. (2016), Ngelambong et al. (2016), Rahimi \& Kozak (2017) consider price as the most critical factor. Other studies such as Subramanian et al. (2016) and Ren et al. (2018) consider service essential. The location also becomes an essential factor (Chen et al., 2017). Most studies also vary in presenting factors that influence a customer's preference for a budget hotel. Therefore, further research is needed to review all the factors identified in previous studies and determine their importance ratings.

Hence, this research aims to learn about the consumer's budget hotels, understand the customer profiles, and determine the most influential factors affecting a budget hotel's customer satisfaction. This research will provide knowledge that is beneficial to managing budget hotels.

\section{Comparison of Budget, Standard, and Luxury Hotel}

Expected customer value at luxurious hotels will be higher than lower-class hotels in terms of quality of services and facilities. Hotel classification is usually divided into three categories, i.e., top-class or prime hotels, standard hotels, and budget hotels. Top class or prime hotels are five-star hotels that offer top-class facilities; some even provide world-class facilities. Simultaneously, standard hotels (three and four-star hotels) and budget hotels (one and two-star hotels) provide standard-level facilities. Nevertheless, three-star hotels intentionally promote themselves as budget hotels. Classification of the hotel provides uniform expectations to customers. The prices of the same products such as overnight rates, food, and beverages in luxury hotels can be higher because of higher customer value, a more substantial investment, and superior staff training (Salanto, 2017). Significant differences between the various classes of hotels are at customer value. Customer value levels can be divided into a quality reputation, value for money, and prestige (Peng et al., 2015).

Meanwhile, the one-star hotel has a minimum of ten rooms, a two-star hotel has a minimum of twenty rooms, a three-star hotel has a minimum of thirty rooms and two suite rooms, a four-star hotel has a minimum of fifty rooms and three suite rooms, and the five-star hotel has minimum of a hundred rooms and four suite rooms. In terms of the number of the restaurant (bar and coffee shop), one-star hotel, two-star hotel, and three-star hotel need at least one, whereas four-star hotel and five-star hotel need at least two. One-star hotel and the twostar hotel are not required to have a function room. Meanwhile, three-star hotels, four-star hotels, and five-star hotels need at least one function room. One-star hotel and two-star hotel are recommended to have recreation and sport. Meanwhile, a three-star hotel is recommended to have recreation and sport and have two other facilities. Four-star hotels and five-star hotels must have recreation and sport and have two other facilities (Peng et al., 2015).

In comparison, one-star hotel and two-star hotel need to have at least one rental room. Three and four-star hotels need at least two rental rooms. A five-star hotel must have at least three rental rooms. Three-star hotels, four-star hotels, and five-star hotels must have a lounge, whereas one-star hotel and two-star hotel are not required to have a lounge. One-star hotel, two-star hotel, three-star hotel, and four-star hotel need a garden. A five-star hotel must have a garden (Ekawati, 2010). 


\section{Definition of Budget Hotel}

The budget hotel concept has been discussed for a long time, and many authors have defined it differently. The term "budget" is widely used in "businesses hotel" (Brotherton, 2004; Fiorentino, 1995; Ren et al., 2018; Subramanian et al., 2016). Brotherton (2004) explained general characteristics of budget hotels such as relatively limited service, ease to access due to its strategic locations, standard bedroom layout and facilities, simple centralized reservation system, and low price strategy. Subramanian et al. (2016) added that budget hotels are usually limited to bed and breakfast services. The customers are also the middle and lowclass consumers, students, and price-conscious business travellers and tourists. Budget hotels show rates around $25-50 \%$ lower than most mid-range hotels and usually offer rooms only (Ren et al., 2016).

The budget hotel's competitive advantage lies in its availability of trade-offs. A study by Almeida (2017), for example, identified that budget hotel guest usually exchange savings in accommodation for much higher spending in other leisure like cultural activities. There is also an increasing trend of branded budget hotels to avoid commoditization. These hotels become a part of international hotel chains and have operational advantages such as a centralized reservation system and broad geographic coverage (Rishi \& Joshi, 2016).

The study by Ngelambong et al. (2016) defined a budget hotel as a necessary accommodation that provides limited service and reasonable room prices that cater to budgetconscious travellers. They reviewed the literature and found that most studies focused on establishing budget hotels, market development, and budget hotels' critical success factors. Hence, more research about customer satisfaction/dissatisfaction of current budget hotels is needed.

\section{Budget Hotel Development in Indonesia}

The first two-star hotel in Indonesia is Formule-1 Hotel by Accor. This hotel has a cleanroom at a low price, but the comfort of stay equivalent to the three-star hotel. In Jakarta, in 2006, Formule-1 Hotel is believed to be one of the forerunners of the budget hotels in Indonesia, followed by Tune Hotels belonging to the AirAsia airline. One year later, in 2007, Santika Group (belonging to Kompas Gramedia) began carrying the same hotel concept. With Amaris brand by Santika, Kompas Gramedia launched the first Amaris Hotel. Amaris Hotel chain was then proliferating until 2014 already has forty one hotels spread all over Indonesia. After Formule-1 Hotel, Tune Hotels, and Amaris Hotel, there were many new budget hotels, like FaveHotel by Aston, @ HOM Hotel by Horison, POP! Hotel, Whiz Hotel, and Ibis Budget Hotel (Barusman et al., 2020)

Budget hotel provides the best value for money to customers (Santra, 2017). Most hotel guests spend much time outside the hotel and only use the hotel to rest at night and eat breakfast at most. For those expecting to spend most of their time outside, a budget hotel is the most reasonable option as they get a lower price compared to a standard hotel but with almost the same room quality (Barusman et al., 20202. High-star hotels offer too many facilities, even more than the customer would even use during their stay. The budget hotel becomes the solution to those situations as the customer would only expect to pay a reduced price, with the worth of the room they use, and they would feel more satisfied as what they pay is what they use (Santra, 2017). 
The factor analysis of demographic, purchasing behaviour, and customer satisfaction of budget hotel

The breakthrough of budget hotels has a significant impact on the hotel industry. Salanto (2017) mentioned that a budget hotel is of the same class as a three-star hotel. However, budget hotels' performance compared to three-star hotels is a lot higher in terms of occupancy rate. As most people look for a good value for money, the idea of a comfortable room with affordable price would appeal to most. Three-star hotels get the most impact of the budget hotel's emergence as they share mostly the same market. Because value given in standard hotels are almost the same as budget hotels, they are expected to cut their price to the same level as budget hotel price.

An accommodation platform may also influence the future of budget hotel businesses likes Airbnb. Airbnb joined the accommodation market in Indonesia from 2013-2014 and had guest growth of $72 \%$ each year. Airbnb stands for Air and "BnB" or Bed and Breakfast. Airbnb is a platform for room, villa, house, and apartment owners to rent their properties at a reasonable price. Room price can be lower than most hotels as they do not need to offer the many facilities that most hotels do. Airbnb claims the average of room owners earned Rp2,36 million income each month in 2016 (Wahono \& Kartika, 2017).

\section{Factors that Influence Customers in Choosing A Budget Hotel}

Ananth et al. (1992) mentioned fifty two influential factors that simplified by Hua et al. (2009) into five critical success factors (tangible product, service quality, price, promotion, and location), which influence travellers to choose a budget hotel. Another study by Ting et al. (2016) explained similar findings: reliability, assurance, tangibility, empathy, responsiveness, and price as factors considered by the traveller to choose a budget hotel. Brotherton \& Shaw (1996) consider competition and market conditions essential. Rivers et al. (1991) found that location proximity, service, room readiness, price, meals quality, loyal customer programme, corporate travel planner, and travel agent are essential factors that influence customer decision. Increasing guest satisfaction may be one factor that can make budget hotels successful by using physical products, staff attributes, and services (Subramanian et al., 2016). A study by Ngelambong et al. (2016) and Ren et al. (2018) found some attributes (value for money, room features, location, service quality, and online travel agencies) can critically improve budget hotel guests' satisfaction.

Appendix 3 shows factors affecting budget hotel customers' satisfaction from previous studies. The researcher, followed by cleanliness, most widely mention price, service, and location. Price is the critical factor that affected customer preference toward the budget hotel (Ting et al., 2016; Brotherton \& Shaw, 1996; Ananth et al., 1992; Rivers et al., 1991; Ngelambong et al., 2016; Rahimi \& Kozak 2017). Service is the critical factor that affected customer preference toward a budget hotel (Ting et al., 2016; Hua et al., 2009; Rivers et al., 1991; Subramanian et al., 2016; Ngelambong et al., 2016; Ren et al., 2018). Location is also a factor to be considered in the critical success factor (Chen et al., 2017; Brotherton \& Shaw, 1996; Hua et al., 2009; Ananth et al., 1992; Rivers et al., 1991; Ngelambong et al., 2016). 


\section{METHODS}

This study uses a quantitative approach with the survey as a research instrument to address the research objectives. The researcher used a systematic research process to conduct a literature study, data collection stages using survey instruments, data verification, data analysis, and answering research questions. This research method is selected after reviewing previous studies with a similar topic. For data analysis, this study uses SPSS software. Units of analysis are some budget hotels in Greater Jakarta. The survey has been distributed directly to the guests of the budget hotels who have checked out from the hotel.

The questionnaire consists of questions to identify the respondents' profiles such as gender, age, income, and educational background. Furthermore, the result is ranked from the highest to the lowest. Our survey variables are customer satisfaction toward the strategic location, size of rooms, cleanliness, availability of SDB, internet connection in rooms, meeting rooms, breakfast, room price, ease of booking such as online booking, brand, and payment method variance.

In total, 363 questionnaires were collected from the budget hotels in the Greater Jakarta areas. The response rate is $100 \%$ because the surveyors intercept the respondents directly in budget hotels, mostly in the lounge and reception area. To better understand the respondents' demographic details and answer the research objectives, we applied several data analysis techniques using SPSS software.

The first technique is descriptive analysis. The data is summarized to describe the sample data and understand the respondent's profile. The second technique is simple regression to test whether the independent variables can be associated with the dependent variable. Finally, nonparametric hypothesis testing is also applied to test importance ratings such as the Friedman test and the Wilcoxon multiple signed ranking test.

\section{RESULTS AND DISCUSSION Results}

Our data consists of 363 responses from 218 male and 145 female respondents. Respondents' main domiciles are Greater Jakarta and Banten, which account for $50.4 \%$ and $14.9 \%$ of total respondents, respectively. Besides, $11.8 \%$ were from West Java and Bali, Central Java, East Java, Kalimantan, Lampung, West Nusa Tenggara, North Sumatera, West Sumatera, South Sumatera, Riau, and Yogyakarta accounted for the remaining 22,9\%. The budget hotel's primary customers are from around Greater Jakarta. It is accustomed to the city lifestyle, which prefers the effectiveness and reasonable values for money deal on a budget hotel.

Among all respondents, 41,6\% spend between Rp2,5-5 million monthly, and 24,8\% spend between Rp5-10 million monthly. The majority of our respondents spend less than Rp10 million monthly. This information reflects that the less someone pays monthly, the more likely they would stay at a budget hotel. In travel, people still based their decision on their daily lifestyle; the more prudent their lifestyle is, the more likely they will stay at a budget hotel.

Table 1 shows that according to Pearson Correlation, there are correlations between age and monthly spending, age and budget of a night stay in a hotel, and between monthly spending and budget of a night stay in a hotel. This means an older person has higher monthly spending and has a higher budget for a night stay in a hotel, and a person with high monthly spending 
The factor analysis of demographic, purchasing behaviour, and customer satisfaction of budget hotel tends to have a higher budget for a night stay in a hotel. There is a negative correlation between monthly spending and frequency of staying in a budget hotel and the budget of a night stay in a hotel and frequency of staying in a budget hotel. It means the more someone spent monthly, the less likely it for that person to stay in a budget hotel, and the more that person's budget is for a night stay in a hotel, the less likely it is for that person to stay at a budget hotel.

Table 1. Pearson Correlation Matrix of Staying in Budget Hotel

\begin{tabular}{|c|c|c|c|c|c|}
\hline & Age & Domicile & $\begin{array}{l}\text { Monthly } \\
\text { Spending }\end{array}$ & $\begin{array}{c}\text { Frequency of stay in } \\
\text { the budget hotel }\end{array}$ & $\begin{array}{c}\text { The budget of a } \\
\text { night stay in a hotel }\end{array}$ \\
\hline Age & 1 & -.073 & $.525^{* *}$ & -.084 & $.137 * *$ \\
\hline Domicile & -.073 & 1 & -.097 & .093 & -.031 \\
\hline Monthly Spending & $.525 * *$ & -.097 & 1 & $-.356^{* *}$ & $.318 * *$ \\
\hline $\begin{array}{l}\text { Frequency of stay in a } \\
\text { budget hotel }\end{array}$ & -.084 & .093 & $-.356 * *$ & 1 & $-.467 * *$ \\
\hline $\begin{array}{l}\text { The budget of a night } \\
\text { stay in the hotel }\end{array}$ & $.137 * *$ & -.031 & $.318 * *$ & $-.467 * *$ & 1 \\
\hline
\end{tabular}

Table 2 shows descriptive statistics of guest satisfaction factors ranked by respondents. The table shows cleanliness as the highest rank and meeting room availability as the lowest rank.

Table 2. Median Rank of Guest Satisfaction Factors

\begin{tabular}{lcccc}
\hline & \multirow{2}{*}{ Factors } & N & \multicolumn{3}{c}{ Percentiles } \\
\cline { 4 - 5 } & & 25th & 50th (Median) & $\mathbf{7 5}^{\text {th }}$ \\
\hline Cleanliness & 363 & 1 & 2 & 3 \\
Price & 363 & 1 & 2 & 4 \\
Location & 363 & 1 & 3 & 4 \\
Room Size & 363 & 3 & 5 & 6 \\
Internet & 363 & 4 & 6 & 8 \\
Breakfast & 363 & 4 & 6 & 8 \\
Booking & 363 & 5 & 7 & 9 \\
Brand & 363 & 5 & 7 & 9 \\
Payment & 363 & 7 & 8 & 11 \\
SDB & 363 & 9 & 10 & 11 \\
Meeting Room & 363 & 8 & 10 & \\
\hline
\end{tabular}

The Friedman test is applied to test whether there is a difference in the respondents' ranks. The Friedman test result is presented in Appendix 7. The test rejects $\mathrm{H}_{0}$ because of the small p-value. It is important to note that the Friedman test informs there are overall differences but does not pinpoint which groups differ from each other. Therefore, a post-hoc test is used to find where the differences occur. Multiple Wilcoxon signed-rank tests have been applied to the different combinations of related groups. Appendix 8 shows the output of the Wilcoxon signedrank test on each of our combinations. Post-hoc analysis with Wilcoxon signed-rank tests was conducted with a Bonferroni correction applied. This study uses a Bonferroni adjustment on the Wilcoxon test results because of multiple comparisons to avoid Type I error. The Bonferroni adjustment is the significance level used (in this case, 0.05) and divides it by the number of tests (55). Therefore, the new significance level of $0.05 / 55$ is 0.0009 . This means that if the p-value is more extensive than 0.0009 , or the result is not statistically significant. 
Based on the findings in Table 3, price and cleanliness have a p-value of 0,00211, which is higher than the significance level of 0,0009 . This means there is no statistically significant difference and both factors have the same level of importance. The location and price are also in the same importance rating because the $\mathrm{p}$-value $(0.41490)$ is higher than 0.0009 . These three factors belong to the first rank of importance. This is because the next pair of comparison, i.e. room size and location, have a p-value of 0,00000, which is lower than the significance level of 0,0009 . It means there is a statistically significant difference, and room size belongs to the second rank of importance.

Internet and room size has a p-value of 0,00000 which means the different rank of important or internet belongs to the third rank of importance. Pair comparison up to the ninth factor (payment) also shows no significant result. All p-values are higher than 0.0009 . Therefore, the internet, breakfast, booking, brand, and payment have the same rank of importance: the third rank of importance.

SDB and payment have a p-value of 0,00000 which is lower than the significance level of 0,0009 . This means there is a statistically significant difference and SDB factor has a different level of importance. Meeting Room and SDB have a p-value of 0.03000 and, therefore, no significant result. Meeting Room and SDB have the same rank of importance: the fourth rank of importance.

Table 3. Post-hoc Analysis Result of Guest Satisfaction Factors

\begin{tabular}{lllll}
\hline No & Factors & Compare with The Previous Factor & Asy. Sig. & Rank \\
\hline 1 & Cleanliness & Cleanliness & & 1 \\
2 & Price & Price & 0.00211 & 1 \\
3 & Location & Location & 0.41490 & 1 \\
4 & Room Size & Room Size & $0.00000^{*}$ & 2 \\
5 & Internet & Internet & $0.00000^{*}$ & 3 \\
6 & Breakfast & Breakfast & 0.17693 & 3 \\
7 & Booking & Booking & 0.00935 & 3 \\
8 & Brand & Brand & 0.00327 & 3 \\
9 & Payment & Payment & 0.00135 & 3 \\
10 & SDB & SDB & $0.00000^{*}$ & 4 \\
11 & Meeting Room & & 0.03000 & 4 \\
\hline
\end{tabular}

\section{Discussion}

Indonesia has wealth in natural beauty, historical heritage treasures, the uniqueness of various ethnic groups, and various cultural festivals that become a great potential tourist attraction for foreign and local visitors. This high attractiveness needs to be balanced with an increase in hotel rooms and other accommodations.

This study shows eleven listed factors potentially represent the importance rating of guest satisfaction factors staying at budget hotels. A budget hotel's guest satisfaction factors can be grouped into four categories. The first category consists of cleanliness, price, and location. The second category consists of room size. Meanwhile, the third category consists of the internet, breakfast, booking, brand, payment. The fourth category consists of SDB and meeting room. The first category is the most important success factors of budget hotels.

Many previous studies mentioned price as the higher rank of importance than cleanliness and location, for example, the study by (Ting et al., 2016; Brotherton \& Shaw 1996; Ananth et 
The factor analysis of demographic, purchasing behaviour, and customer satisfaction of budget hotel

al., 1992; Rivers et al., 1991; Ngelambong et al., 2016). Other studies, e.g., (Brotherton \& Shaw, 1996; Rivers et al., 1991), ranks cleanliness after price. Location is also an essential factor in the study by (Brotherton \& Shaw 1996; Hua et al., 2009; Ananth et al., 1992; Rivers et al., 1991; Ngelambong et al., 2016).

Several managerial implications can be identified from this study. First, this study's findings can be used in industry and academia by providing clues on how best to approach the challenge of budget hotels development in Indonesia. The analysis results show that the more person spends monthly, the less likely he/she would stay at a budget hotel as they can pay for a higher accommodation than a budget hotel. Therefore, budget hotels can focus on the customer segment with a monthly income of about Rp2,5-5 million, as $41,6 \%$ of the respondents are frequent budget hotel customer. Secondly, it is reasonable to assume that older people potentially have higher monthly spending and budgets for hotel stays and are therefore less likely to stay in budget hotels. As a result, budget hotels may adjust their advertising method to attract younger customers, as they are proven to have just the proper budget to stay at a budget hotel. Finally, this research identifies the significant factors affecting guest satisfaction, such as cleanliness and price and location, as the first rank of importance. This result suggests that a budget hotel must consider these three factors essential for their service. The other factors should be implemented, though they can only be considered less critical.

\section{CONCLUSION}

This paper carried out a comprehensive study to identify the critical guest satisfaction factors in the budget hotels business. The major contributions of this study are to present a rank of importance of guest satisfaction factors. The previous study mostly tries to identify the factors but rarely discusses their rank of importance. This study found the first rank of importance consists of three guest satisfaction factors (cleanliness, price, and location), followed by room size as the second important. There are eleven factors grouped into six different ranks of importance in total and the typical profile of budget hotel guests has also been described.

Academia and practitioners need to understand budget hotels' business development because this sector is promising. Increased competition and customer expectations have to be addressed effectively to guarantee competitiveness and business sustainability in the future.

This study has several limitations in its scope and generalizability. The current study mostly examines budget hotels in Greater Jakarta. Although this area is one of Indonesia's largest budget hotel markets, other important areas, such as Bali, still need further research. Therefore, the scope of further study becomes wider and can verify the findings of this study. Further study can use an in-depth interview approach to explain why respondents have assigned this guest satisfaction rating.

\section{ACKNOWLEDGEMENT}

I want to thank an anonymous referee for their valuable comments and suggestions. Funding for this project comes from the Research Grant provided by Universitas Prasetiya Mulya. 


\section{REFERENCES}

Almeida, A. (2017). Budget Hotels in Madeira: Prospects and Market Trends. European Journal of Applied Business and Management, Special Issue, 348-358. https://nidisag.isag.pt/index.php/IJAM/article/view/197.

Ananth, M., DeMicco, F. J., Moreo, P. J., \& Howey, R. M. (1992). Marketplace Lodging Needs of Mature Travellers. Cornell Hotel and Restaurant Administration Quarterly, 33(4), 1224. http://dx.doi.org/10.1016/0010-8804(92)90005-P.

Barusman, A. R. P., Virgawenda, T. M. B., \& Arwis, Y. A. (2020). Factors that Effect the Level of Consumers Loyalty for Budget Hotel in Indonesia. Journal of Talent Development and Excellence, 13(1), https://www.iratde.com/index.php/jtde/article/view/1157.

BPS. (2016). Statistical Yearbook of Indonesia 2016 (2016th ed.). Retrieved January 72020 from

https://www.bps.go.id/publication/2016/06/29/7aa1e8f93b4148234a9b4bc3/statistikindonesia-2016.html.

BPS. (2018). Hotel and Other Accommodation Statistics in Indonesia 2018. Retrieved January $72020 \quad$ from https://www.bps.go.id/publication/2019/04/11/d64817c1f0294f59556bc76b/statistikhotel-dan-akomodasi-lainnya-di-indonesia-2018.html.

BPS. (2019). Statistical Yearbook of Indonesia 2019. Retrieved January 72020 from https://www.bps.go.id/publication/2019/07/04/daac1ba18cae1e90706ee58a/statistikind onesia-2019.html.

BPS. (2020). Hotel and Other Accommodation Statistics in Indonesia 2019. Retrieved January $72020 \quad$ from https://www.bps.go.id/publication/2020/07/03/4206448bd185bf883b73d414/statistikhotel-dan-akomodasi-lainnya-di-indonesia-2019.html.

Brotherton, B. (2004). Critical Success Factors in UK Budget Hotel Operations. International Journal of Operations \& Production Management, 24(9), 944-969. https://doi.org/10.1108/01443570410552135.

Brotherton, B. \& Shaw, J. (1996). Towards an Identification and Classification of Critical Success Factors in UK Hotels Plc. International Journal of Hospitality Management, 15(2), 113-135. https://doi.org/10.1016/0278-4319(96)00014-X.

Chen, Y., Xiao, L., \& Mi, C. (2017). Opinion Mining from Online Reviews: Consumer Satisfaction Analysis with B\&B Hotels. PACIS 2017 Proceedings. Pacific Asia Conference on Information Systems, Langkawi, Malaysia. https://aisel.aisnet.org/pacis2017/81/.

Ekawati, S. K. (2010). Pangandaran Beach Resort Hotel di Pangandaran. Thesis, Universitas Atma Jaya Yogyakarta. Retrieved January 22020 from http://e-journal.uajy.ac.id/2058/. 
The factor analysis of demographic, purchasing behaviour, and customer satisfaction of budget hotel

Euromonitor International. (2018). Lodging in Indonesia: Country Report, September 2018 (11). Euromonitor International. Retrieved January 172020 from http://www.portal.euromonitor.com/portal/analysis/related.

Euromonitor International. (2019). Lodging in Indonesia: Country Report September 2019 (10). Euromonitor International. Retrieved 17 January 2020 from https://www.portal.euromonitor.com/portal/Analysis/Tab.

Euromonitor International. (2020). Brand Shares: Hotels Indonesia. Retrieved 17 January 2020 from https://www.portal.euromonitor.com/portal/statisticsevolution/index.

Filippini, R. (1997). Operations Management Research: Some Reflections on Evolution, Models, and Empirical Studies in OM. International Journal of Operations \& Production Management, 17(7), 655-670. https://doi.org/10.1108/01443579710175583.

Fiorentino, A. (1995). Budget Hotels: Not just Minor Hospitality Products. Tourism Management, 16(6), 455-462. https://doi.org/10.1016/0261-5177(95)00054-R.

Hua, W., Chan, A., \& Mao, Z. (2009). Critical Success Factors and Customer Expectation in Budget Hotel Segment-A Case Study of China. Journal of Quality Assurance in Hospitality \& Tourism, 10(1), 59-74. https://doi.org/10.1080/15280080802713702.

Ngelambong, A., Kibat, S. A., Azmi, A., Nor, N. M., \& Saien, S. (August 2016). An examination of guest dissatisfaction in budget hotel: A content analysis of guest review on TripAdvisor. Conference: International Research Symposium in Service Management. $\quad$ Retrieved $\quad$ January $\quad 17 \quad 2020$ from https://www.researchgate.net/publication/308888674_An_examination_of_guest_dissat isfaction_in_budget_hotel_a_content_analysis_of_guest_review_on_TripAdvisor/citati ons.

Nunkoo, R., Teeroovengadum, V., Thomas, P., \& Leonard, L. (2017). Integrating Service Quality as a Second-Order Factor in a Customer Satisfaction and Loyalty Model. International Journal of Contemporary Hospitality Management, 29(12), 2978-3005. https://doi.org/10.1108/IJCHM-11-2016-0610.

Peng, J., Zhao, X. \& Mattila, A. S. (2015). Improving Service Management in Budget Hotels. International Journal of Hospitality Management, 49, 139-148. https://doi.org/10.1016/j.ijhm.2015.06.005.

Rahimi, R. \& Kozak, M. (2017). Impact of Customer Relationship Management on Customer Satisfaction: The Case of a Budget Hotel Chain. Journal of Travel \& Tourism Marketing, 34(1), 40-51. https://doi.org/10.1080/10548408.2015.1130108.

Ren, L., Qiu, H., Ma, C., \& Lin, P. M. C. (2018). Investigating Accommodation Experience in Budget Hotels. International Journal of Contemporary Hospitality Management, 30(7), 2662-2679. https://doi.org/10.1108/IJCHM-11-2016-0625.

Ren, L., Qiu, H., Wang, P. \& Lin, P. M. C. L. (2016). Exploring Customer Experience with Budget Hotels: Dimensionality and Satisfaction. International Journal of Hospitality Management, 52, 13-23. https://doi.org/10.1016/j.ijhm.2015.09.009. 
Rishi, M. \& Joshi, G. (2016). Emerging Challenges for Branded Budget Hotels in India: Thematic Analysis of Managers' Perceptions and Customer Expectations. Worldwide Hospitality and Tourism Themes, 8(1), 61-82. https://doi.org/10.1108/WHATT-102015-0038.

Rivers, M. J., Toh, R. S., \& Alaoui, M. (1991). Frequent-Stayer Programs: The Demographic, Behavioral, and Attitudinal Characteristics of Hotel Steady Sleepers. Journal of Travel Research, 30(2), 41-45. https://doi.org/10.1177/004728759103000209.

Rozano, B. \& Pamungkas, P. (2016). Pengaruh Kualitas Layanan terhadap Kepuasan dan Loyalitas Pelanggan Hotel Bujet di Bandung. Tourism Scientific Journal, 2(1), 104-127. https://doi.org/10.32659/tsj.v2i1.20.

Salanto, F. (2017). Jakarta Hotel (Q2 2017; Colliers Quarterly). Colliers International $\begin{array}{lllll}\text { Indonesia. } & \text { Retrieved } & \text { January } & 10 & 2020\end{array}$ https://id.scribd.com/document/370711252/q2-2017-Colliersquarterly-Jakarta-Hotel.

Santra, K. I. (2017). Using Structural Equation Modeling to Assess the Budget Hotel Performance in Bali Indonesia. International Journal of Mechanical Engineering and Technology, 8(7), 933-951. http://www.iaeme.com/IJMET/issues.asp?JType=IJMET\&VType=8\&IType=7.

Subramanian, N., Gunasekaran, A., \& Gao, Y. (2016). Innovative Service Satisfaction and Customer Promotion Behaviour in the Chinese Budget Hotel: An Empirical Study. International Journal of Production Economics, 171(2), 201-210. https://doi.org/10.1016/j.ijpe.2015.09.025.

Ting, C. Y., Mang, L. E., Yao, N. C., \& Shau, W. C. (2016). Factors that Affecting Customer Satisfaction among Local Tourists Toward Budget Hotels in Malaysia. Thesis. Universiti Tunku Abdul Rahman. Retrieved January $13 \quad 2020$ from https://www.google.com/url?sa=t\&rct=j\&q=\&esrc=s\&source=web\&cd=\&ved=2ahUK EwjoueaRvpPwAhVMbn0KHcqeCeYQFjAAegQIAxAD\&url=http\%3A\%2F\%2Feprin ts.utar.edu.my\%2F2017\%2F1\%2FMK-2016-1201475.pdf\&usg=AOvVaw1ckHUeVngzslIGh91K3GU.

Wahono, F. A. \& Kartika, E. W. (2017). Consumer Behavior Study on the Acceptance of Airbnb from Consumer in Surabaya, Indonesia. Jurnal Hospitality dan Manajemen Jasa, 5(2). $\quad$ http://publication.petra.ac.id/index.php/manajemenperhotelan/article/view/6042.

Appendix 1. Sales Growth of Budget Hotels (in Billions Rupiah)

\begin{tabular}{lcccccc}
\hline \multicolumn{1}{c}{ Brand Name } & $\mathbf{2 0 1 4}$ & $\mathbf{2 0 1 5}$ & $\mathbf{2 0 1 6}$ & $\mathbf{2 0 1 7}$ & $\mathbf{2 0 1 8}$ & $\mathbf{2 0 1 9}$ \\
\hline Favehotel & 738 & 754 & 778 & 864 & 1092 & 1050 \\
Ibis Budget Hotel & 201 & 212 & 234 & 256 & 218 & 269 \\
Pop! Hotel & 184 & 310 & 343 & 379 & 401 & 465 \\
Amaris Hotel & 479 & 565 & 588 & 667 & 656 & 649 \\
\hline
\end{tabular}

Source: Euromonitor International (2020) 
Simangunsong, E.

The factor analysis of demographic, purchasing behaviour, and customer satisfaction of budget hotel

Appendix 2. Growth of Accommodation Businesses, 2012 -2019 (in Number of Hotels)

\begin{tabular}{lccccc}
\hline \multicolumn{1}{c}{ Type of Hotel } & $\mathbf{2 0 1 2}$ & $\mathbf{2 0 1 3}$ & $\mathbf{2 0 1 4}$ & $\mathbf{2 0 1 5}$ & $\mathbf{2 0 1 6}$ \\
\hline Star Hotel & 1623 & 1778 & 1996 & 2197 & 2387 \\
5 Star & 138 & 155 & 160 & 172 & 183 \\
4 Star & 297 & 335 & 376 & 422 & 453 \\
3 Star & 509 & 554 & 668 & 739 & 839 \\
2 Star & 333 & 374 & 437 & 496 & 528 \\
1 Star & 346 & 360 & 355 & 368 & 384 \\
Non Star Accommodation & 14375 & 14907 & 15488 & 16156 & 16442 \\
Total & 15998 & 16685 & 17484 & 18353 & 18829 \\
\hline
\end{tabular}

Source: BPS (2016), BPS (2018), and BPS (2020)

Appendix 3. Factors Affecting Budget Hotels Customers' Satisfaction

\begin{tabular}{|c|c|}
\hline Authors & Guest Satisfaction Factors \\
\hline \multirow[t]{4}{*}{ Ananth et al. (1992) } & (1) \\
\hline & Convenience of location \\
\hline & Security \\
\hline & Quality \\
\hline \multirow{5}{*}{$\begin{array}{l}\text { Brotherton \& Shaw } \\
\text { (1996) }\end{array}$} & Hygiene and cleanliness \\
\hline & Value for money accommodation \\
\hline & Convenient locations \\
\hline & Consistent accommodation standards \\
\hline & Central sales/reservation system \\
\hline \multirow[t]{4}{*}{ Chen et al. (2017) } & First factors: location and facility quality \\
\hline & $\begin{array}{l}\text { Second factors: price level, room quality, service quality, surrounding } \\
\text { environment, and specialties }\end{array}$ \\
\hline & Third factors: consumption emotion \\
\hline & Fourth factors: expectation fulfillment and perceived value \\
\hline \multirow[t]{2}{*}{ Ting et al. (2016) } & Price \\
\hline & Service quality (reliability, assurance, tangibility, empathy, and responsiveness) \\
\hline \multirow[t]{2}{*}{ Hua et al. (2009) } & Service quality \\
\hline & Location \\
\hline \multirow[t]{6}{*}{ Ngelambong et al. (2016) } & Value for money \\
\hline & Service quality (tangibles, reliability, responsiveness, assurance, and empathy) \\
\hline & Location \\
\hline & Online booking \\
\hline & Guest comments \\
\hline & Room features \\
\hline \multirow[t]{2}{*}{ Rahimi \& Kozak, (2017) } & Value for money \\
\hline & Core products offering \\
\hline \multirow[t]{3}{*}{ Ren et al. (2018) } & Quality of core products \\
\hline & Sensorial perceptions \\
\hline & Value for money \\
\hline \multirow[t]{4}{*}{ Rivers et al. (1991) } & Readiness of rooms \\
\hline & Low or discount price \\
\hline & Overall services quality \\
\hline & Convenience of location \\
\hline \multirow{2}{*}{$\begin{array}{l}\text { Subramanian et al. } \\
\text { (2016) }\end{array}$} & $\begin{array}{l}\text { Physical product (standardized hotel design, proper size of guest bedroom, } \\
\text { bedroom comfort level hygiene, and proper interior and exterior colour) }\end{array}$ \\
\hline & Services (service efficiency, security and safety, and service speed) \\
\hline
\end{tabular}


BISMA (Bisnis dan Manajemen) Volume 13 Issue 2, April 2021 Page 121-134

E-ISSN 2549-7790, P-ISSN 1979-7192

Appendix 4. Domicile of Respondents

\begin{tabular}{|c|c|c|}
\hline Region & Frequency & Percentage \\
\hline Bali & 5 & 1.4 \\
\hline West Java & 43 & 11.8 \\
\hline Central Java & 23 & 6.3 \\
\hline East Java & 18 & 5.0 \\
\hline Greater Jakarta & 183 & 50.4 \\
\hline Banten & 54 & 14.9 \\
\hline Kalimantan & 7 & 1.9 \\
\hline Lampung & 4 & 1.1 \\
\hline West Nusa Tenggara & 1 & 0.3 \\
\hline North Sumatera & 9 & 2.5 \\
\hline West Sumatera & 3 & 0.8 \\
\hline South Sumatera & 7 & 2 \\
\hline Riau & 1 & 0.3 \\
\hline Yogyakarta & 5 & 1.4 \\
\hline
\end{tabular}

Appendix 5. Monthly Spending of Respondents

\begin{tabular}{lcc}
\hline \multicolumn{1}{c}{ Spending } & Frequency & Percentage \\
\hline$<$ Rp2,5 million & 65 & 17.9 \\
Rp2,5 - 5 million & 151 & 41.6 \\
Rp5 - 10 million & 90 & 24.8 \\
Rp10 - 20 million & 35 & 9.6 \\
$>$ Rp20 million & 22 & 6.1 \\
Total & 363 & 100.0 \\
\hline
\end{tabular}

Appendix 6. Friedman Test Statistics Result

\begin{tabular}{cccc}
\hline $\mathbf{N}$ & Chi-Square & Df & Asymp. Sig. \\
\hline 363 & 1907.226 & 10 & .000 \\
\hline
\end{tabular}

